\title{
FAFÁ DOMIDO
}

\section{José Luis Rivas}

Là! L'Asie. Sol miré...

¡La! La así. Sola. Mido si, solfado, resido do la famila Dodó fado resolfa. Mila si, domido do sol dolado, fafá Dodó la mimí solfa. Sí, lado do sol, fafá la la mimí solfa ... ¡resolfa! ¡La, la! Sola la así y sola a mi lado la domí. ¡Sí, sí! ¡La adola mi fado relamido! LPyH

Fafá domido

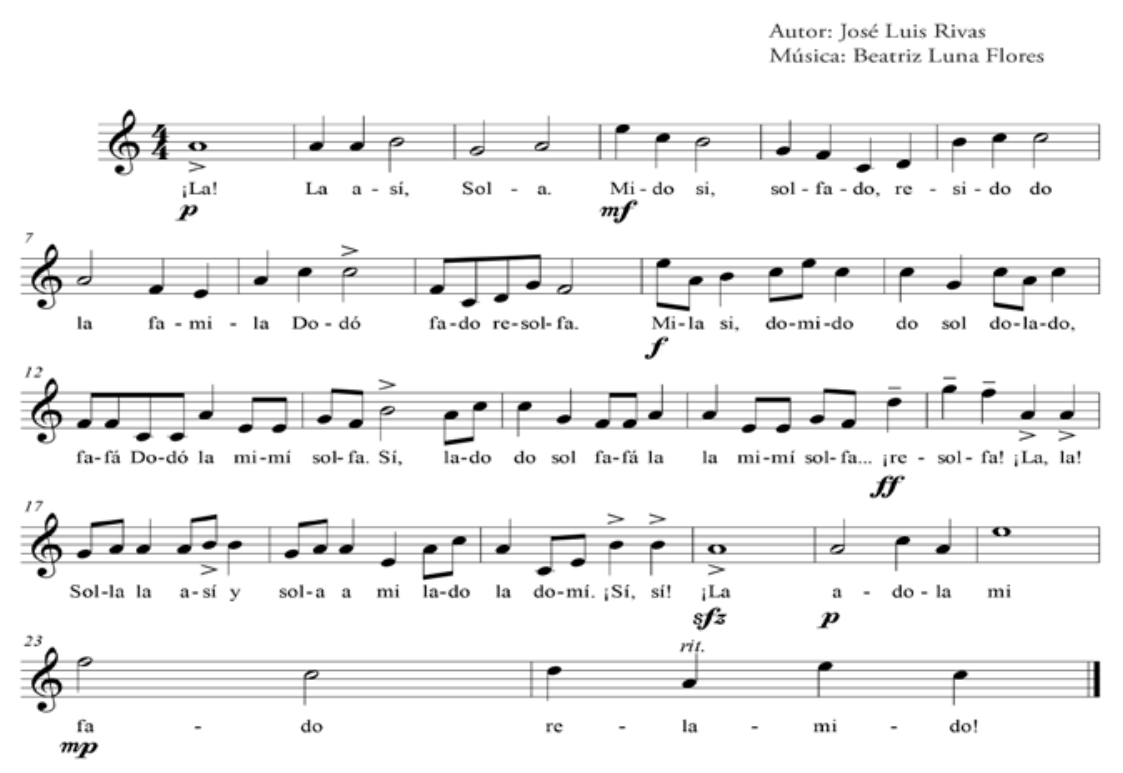

